\title{
Analisis Pengaruh Antara Economic Value Edded (EVA), Net Operating Profit After Tax (NOPAT), dan Weighted Average Cost of Captal (WACC) terhadap Market Value Added (MVA) pada perusahaan LQ-45
}

\author{
Soedewi Soedorowedi dan Adelia Savitri \\ Fakultas Ekonomi Universitas Airlangga
}

\begin{abstract}
Abstrak
Penelitian ini bertujuan untuk membuktikan hasil perdebatan Steren Stewart dengan Pablo Fernandez dan D.V. Ramana mengenai hubungan EVA dan unsur-unsur yang membentuk EVA meliputi NOPAT dan WACC terhadap MVA melalui pendekatan secara kuantitatif, dengan metode purposive sampling diperoleh 10 perusahaan yang masuk dalam kategori perusahaan LQ-45 yang layak diteliti sesuai dengan syarat yang ditentukan. Berdasarkan hasil pengujian hipotesis dapat disimpulkan terdapat hubungan posotif yang kuat antara variabel EVA denan MVA. Sedangkan untuk model yang kedua diperoleh bahwa variabel NOPAT dan WACC secara simultan mampu menjelaskan MVA sebesar 80,1\% dan sisanya sebesar 19,9\% dijelaskan oleh variabel lain. Untuk penelitian secara parsial didapatkan NOPAT berpengaruh signifikan terhadap MVA begitu juga dengan WACC berpengaruh signifikan terhadap MVA>
\end{abstract}

Kata kunci: Economic value added (EVA), Net Operating Profit After Tax (NOPAT), dan Weighted Average Cost of Captal (WACC) terhadap Market Value Added (MVA) 